Sanja Doncic ${ }^{1}$

Business applied studies Academy, Belgrade
ORIGINAL SCIENTIFIC ARTICLE doi: 10.5937/ekonomika2003073D

Received: May, 22. 2020.

Accepted: July, 08. 2020.

\title{
TESTING THE CAUSALITY BETWEEN BITCOIN PRICE AND THE GOLD PRICE IN THE GLOBAL MARKET PRIME BY GRANGER'S TEST
}

\begin{abstract}
The paper examines the existence of a causal relationship in Grangers' sense between the movement of Bitcoin prices and the price of gold at the global financial market, in order to answer the question whether it is possible to predict the movement of the Bitcoin price based on the movement of the price of gold in the world market, but also vice versa. The survey was conducted from January 1, 2019 to December 1, 2019. In the research was used the Granger causality test (1969). The research results show that historical data on the movement of gold prices in the world market cannot be used to predict the change in value and price movements of Bitcoin. On the other hand, the survey results indicate the possibility of a reliable application of the use of historical data on the movement of value and price of Bitcoin.
\end{abstract}

Key words: the Granger causality test, Bitcoin, VAR model, VECM model

JEL classification: $C 22, C 23$

\section{ТЕСТИРАҢЕ КАУЗАЛНОСТИ ИЗМЕЪУ БИТЦОИНА И ЦЕНЕ ЗЛАТА НА СВЕТСКОМ ТРЖИШТУ ПРИМЕНОМ ГРАНГЕРОВОГ ТЕСТА}

\begin{abstract}
Апстракт
У раду се испитује каузална веза у Гренгеровом смислу између кретања иене Битиоина и цеене злата на глоалном финансијском тржиђту како би се одговорило на питање да ли је могуће предвидети кретағе цеене Битияонна на основу кретаға ичене злата на светском тржниту, али и обратно. Истраживање је спроведено у периоду д 1 јануара 2019. Године до 1. децембра 2019. Године. У истражсивағу је коришћен Гренгеров теста каузалности (1969). Резултати истражсивања показују да историјским подаци о кретағу иене злата на светском тржишту не могу да се користе за предвиђағе промена у вредности и цеени Битцоина. Са друге стране, резултати истраживања указују да је могућа поуздана примена историјских података о кретању вредности и цене Битцоина за предвиђање цуене злата.
\end{abstract}

Кључне речи: the Granger causality mест, Bitcoin, VAR модел, VЕCM модел

${ }^{1}$ belosevic.sanja@yahoo.com, ORCID ID 0000-0002-9300-8284 


\section{Introduction}

The subject of special interest in the recent years of the media, professional and scientific public is the possibility of predicting the movement of the value and price of Bitcoin, not only because of the growth of its value as electronic money, but also because of the growing interest in Bitcoin as a financial and speculative asset (Kristoufek, 2014, Smigić-Miladinović, 2018). Specifically, the rise in its popularity, thanks in large part to the rapid growth in its value, has caused an increasing number of scientific papers to examine the relationship between Bitcoin trading volume and its value. The causality between the trading volume of an asset and the growth of its value has been explored in numerous papers and its mechanisms are more or less commonly known by Karpoff (1987), Li et al., 2016), (Balduzzi et al., 2001), (Chiarella et al. , 2016) and (Puri and Philippatos, 2008). Characteristic of the market is the appearance of nonlinearities and structural breaks in the data on the historical movement of values and prices of Bitcoin. From this reason investigation of this phenom requires the application of non-parametric tests. Hence, previous studies, such as the research by Balcilar et al (2017) examined the possibility of predicting the price and value of Bitcoin by applying non-parametric tests that focused on analyzing the causality between Bitcoin trading volume and Bitcoin yield and volatility. Typically, these studies were used a causality-in-quantiles test to examine the causally-consequential relationship between selected phenomena. However, the results of these studies indicate that trading volume can be used to predict the yield and value of Bitcoin, except in a situation where the Bitcoin market is in bear and bull mode. Also, research indicates that trading volume cannot be used to predict yield volatility at any point of conditional distribution. The possibility of establishing a causal relationship between trading volume and the price of Bitcoin indicates a weak form of inefficiency of this market as trading volume information is transmitted to the market and embedded in its value (Chen et al., 2001). In the context of the efficient market hypothesis and the martingale of the process describing the efficient market, this means that this market is inefficient and that all econometric models built on the "random walk" hypothesis, that is, the asset valuation models based on the hypothesis of market efficiencies are not realistic (Radivojevic, 2014, 2015, 2017a,b). This indicates that models that are not based on the efficient market hypothesis should be used to predict the value movement, or price of Bitcoin.

Adding to the foregoing the fact that in recent years the Bitcoin market has been $\mathrm{s}$, in a constant mode of bear-and-bull regimes, and is quite volatile, then there is a need to look at other ways of predicting movement of price and retursn of Bitcoin. Since in recent years the gold market has also been the subject of considerable interest, primarily because of its volatility and reflection of global economic trends, not only those related to economic and financial flows, but also broader, socio-political, so it is very interesting to consider the possibility of using data on the movement of the price of gold in the global market in the context of the ability to predict the movement of value and price of Bitcoin. This is especially important given that the gold market is a reflection of global economic developments, on the one hand, and the fact that Bitcoin is becoming increasingly important as an asset, ie. investment alternative, on the other hand. Therefore, the purpose of this paper is to apply the Granger causality test in order to answer to the question of whether the movement of the price of Bitcoin at the global financial market can be predicted on the basis of the movement of the gold price. 


\section{Theoretical background of the issue in the context of the methodology used}

In the context of the subject matter of the research of this paper, the application of the Granger causality test would imply that based on a set of data on the movement of gold price it would be possible to forecast a future movement of Bitcoin price better than only conducting such forecast on the basis of the time series of the historical data about the Bitcoin price movement. In other words, on the assumption that there is an available set of information about the movement of the gold price (x) and the movemnet of price of Bitcoin (y) at a certain moment ( $t$ ) (the information set $\left.\Omega_{t}\right)$ of the form $\left(x_{t}, \ldots . x_{t-j}, y_{t}\right.$, $\left.\ldots . . \mathrm{y}_{\mathrm{t}-\mathrm{i}}\right)$, the data about gold price at the moment $(\mathrm{t})\left(\mathrm{x}_{\mathrm{t}}\right)$ can be said to be Granger-causal for the Bitcoin price data $\left(\mathrm{y}_{\mathrm{t}}\right)$ wrt. $\Omega_{\mathrm{t}}$ if the variance of the optimal linear predictor for predicting a Bitcoin price at the moment $\mathrm{t}+\mathrm{h}\left(\mathrm{y}_{\mathrm{t}+\mathrm{h}}\right)$, based on the available set of pieces of information at the moment $(\mathrm{t})\left(\Omega_{\mathrm{t}}\right)$ has a smaller variance than the optimal linear predictor for $\mathrm{y}_{\mathrm{t}+\mathrm{h}}$ only based on the data about the movement of the gold price from the prior period, for any $h$.

For the reason of the said, the data about the gold price $(\mathrm{x})$ can be said to Grangercause $y$ if, and only if $\sigma^{2}{ }_{1}\left(y_{t}: y_{t-j}, x t-i\right)<\sigma^{2}{ }_{2}\left(y_{t}: y_{t-j}\right)$, with $j$ and $i=1,2,3, \ldots . n$, and $\sigma^{2}$ representing the variance of the forecast error.

Mathematically, the above can be expressed as follows (Granger, 1969):

$$
B_{t}=\alpha+\sum_{t=1}^{m} \beta_{i}(B)_{t-i}+\sum_{j=1}^{n} \tau_{j}(\mathrm{~A} u)_{t-j}+\mu_{t}
$$

и

$$
A u_{t}=\theta+\sum_{t=1}^{p} \phi_{i}(A u)_{t-i}+\sum_{j=1}^{q} \psi_{j}(B)_{t-j}+\eta_{t}
$$

Where are:

- Au-gold price

- $B$ - Bitcoin price

- $\quad \mu$ and $\eta$ are the residuals which are assumed to $\mu$ and $\eta \sim \operatorname{IID} N(0,1)$.

According to Radivojevic et al. (2019), using the least squares method, it is possible to test the following four hypotheses:

1. that there is unidirectional causality from a change in Bitcoin price towards a change in the gold price, but not the other way around. Mathematically stated:

$$
\sum_{j=1}^{n} \tau_{j} \neq 0 \text { и } \sum_{j=1}^{q} \psi_{j}=0
$$

The foregoing means that a change in the price of Bitcoin increases the prediction of a change in the price of gold. 
2. that there is unidirectional causality from a change in the gold price towards a change in a Bitcoin price, or:

$$
\sum_{j=1}^{n} \tau_{j}=0 \text { и } \sum_{j=1}^{q} \psi_{j} \neq 0
$$

3. that there is the Granger causality in any direction whatsoever, i.e. that:

$$
\sum_{j=1}^{n} \tau_{j} \neq 0 \text { и } \sum_{j=1}^{q} \psi_{j} \neq 0
$$

4. that there is no Granger causality in any direction whatsoever, i.e. that:

$$
\sum_{j=1}^{n} \tau_{j}=0 \text { и } \sum_{j=1}^{q} \psi_{j}=0
$$

The application of the Granger causality test boils down to proving one of these hypotheses, which provides an answer to the question whether a change in the value and price of Bitcoin can be predicted based on a change in the price of gold.

\section{An empirical study of Granger causality between Bitcoin price and the price of gold}

Data of movements of the Gold price and Bitcoin price were collected from CoinMarketCap's official website for the period January 1 - December 31, 2019. Daily data on the price of gold and Bitcoin price were used, noting that the price of gold is expressed in dollars. The daily logarithmic ${ }^{2}$ yield rates were calculated using the following form:

$$
R_{i, t}=\log \left(\frac{P_{i, t}}{P_{i, t-1}}\right)
$$

Where are:

$\mathrm{R}_{\mathrm{i}, \mathrm{t}}$ - The rate of return of gold / Bitcoin in a day $(\mathrm{t})$.

$\mathrm{P}_{\mathrm{i}, \mathrm{t}}$ - represents the price of gold / Bitcoin in a day $(\mathrm{t})$.

The first step in the application of the Granger causality test implied the examination of the stationarity of the time series and the determination of the number of the unit roots (the order of integration). For that purpose, the ADF test was used in the paper. The results of this test are given in Table 1 .

\footnotetext{
${ }^{2}$ See Radivojevic et al (2016) for more details on the reasons for applying logarithmic returns.
} 
Table 1. The results of ADF test

\begin{tabular}{|l|c|c|c|c|}
\hline \multirow{2}{*}{ Variables } & \multicolumn{2}{|c|}{ Level } & \multicolumn{2}{c|}{ Difference } \\
\cline { 2 - 5 } & stat. & p-value & stat. & p-value \\
\hline Bitcoin & 1.998 & 0.1147 & 16.608 & 0.000 \\
\hline Gold & 0.000 & 0.000 & & \\
\hline
\end{tabular}

Source: (Author's)

As can be seen, the Bitcoin returns time series has the non-stationarity problem in level data. It was only after the application first difference technique was used the series is become stationaty. As both series were not non-stationary at the same level, no cointegration test was used in the paper. In the case where both series are non-stationary at the same level, some of the cointegration tests should be applied (see Curcic, et al. 2020 for details). According to Curcic, et al. (2020) in the case of cointegration, instead of the VAR model, it is necessary to use the VECM model. After testing for stationarity, the optimal lenght length was determined in the paper. For this purpose, the ACI criterion was used in the paper. According to this criterion the optimal lag length in the case of Bitcoin is 10 (-6.885), while in the case of gold it is $1(-3.773)$. Table 2 .

The resuts of the Granger causality test for the equation (1) and (2) are shown in

Table 2. The resuts of the Granger causality test for the equation (1) and (2)

\begin{tabular}{|l|c|c|c|c|c|}
\hline & Coefficient & Std. Error & $t$-ratio & $p$-value & \\
\hline const & 0.000612532 & 0.00228597 & 0.2680 & 0.7890 & \\
\hline gold_1 & 0.0104406 & 0.0642810 & 0.1624 & 0.8711 & \\
\hline gold_2 & -0.0158977 & 0.0634715 & -0.2505 & 0.8024 & \\
\hline gold_3 & -0.107711 & 0.0632175 & -1.704 & 0.0897 & $*$ \\
\hline gold_4 & 0.00328073 & 0.0637074 & 0.05150 & 0.9590 & \\
\hline gold_5 & 0.0778247 & 0.0635394 & 1.225 & 0.2219 & \\
\hline gold_6 & -0.0567166 & 0.0632926 & -0.8961 & 0.3711 & \\
\hline gold_7 & -0.0972254 & 0.0633583 & -1.535 & 0.1262 & \\
\hline gold_8 & 0.122348 & 0.0643424 & 1.902 & 0.0584 & $*$ \\
\hline d_Bit_1 & 0.343314 & 0.307601 & 1.116 & 0.2655 & \\
\hline d_Bit_2 & 0.337510 & 0.400330 & 0.8431 & 0.4000 & \\
\hline d_Bit_3 & 0.515127 & 0.443662 & 1.161 & 0.2468 & \\
\hline d_Bit_4 & 0.838642 & 0.456556 & 1.837 & 0.0675 & $*$ \\
\hline d_Bit_5 & 0.782688 & 0.459806 & 1.702 & 0.0900 & $*$ \\
\hline d_Bit_6 & 0.924008 & 0.445360 & 2.075 & 0.0391 & $* *$ \\
\hline d_Bit_7 & 0.615623 & 0.396731 & 1.552 & 0.1221 & \\
\hline d_Bit_8 & -0.0267461 & 0.305144 & -0.08765 & 0.9302 & \\
\hline R-squared & 0.073728 & & F-tests of zero restrictions: & & \\
\hline \multicolumn{7}{|l|}{} & 1.3428 & {$[0.2231]$} & & & \\
\hline $\begin{array}{l}\text { All lags of gold } \\
\text { F(8,237) }\end{array}$ & & & & & \\
\hline
\end{tabular}




\begin{tabular}{|c|c|c|c|c|c|}
\hline $\begin{array}{l}\text { All lags of } \\
\text { d_Bit } F(8, \\
237)=1.0521 \\
{[0.3977]}\end{array}$ & 1.0521 & [0.3977] & & & \\
\hline \multirow{2}{*}{$\begin{array}{l}\text { All vars, lag } \\
8 \quad F(2, \\
237)=1.8148 \\
{[0.1651]}\end{array}$} & 1.8148 & {$[0.1651]$} & & & \\
\hline & Coefficient & Std. Error & t-ratio & p-value & \\
\hline const & 0.000 & 0.000475469 & -0.03103 & 0.9753 & \\
\hline gold_1 & 0.00551133 & 0.0133701 & 0.4122 & 0.6806 & \\
\hline gold_2 & 0.00735445 & 0.0132017 & 0.5571 & 0.5780 & \\
\hline gold_3 & -0.0185087 & 0.0131489 & -1.408 & 0.1606 & \\
\hline gold_4 & -0.00649274 & 0.0132508 & -0.4900 & 0.6246 & \\
\hline gold_5 & 0.00391543 & 0.0132159 & 0.2963 & 0.7673 & \\
\hline gold_6 & -0.0120088 & 0.0131645 & -0.9122 & 0.3626 & \\
\hline gold_7 & -0.0304292 & 0.0131782 & -2.309 & 0.0218 & $* *$ \\
\hline gold_8 & 0.00935434 & 0.0133829 & 0.6990 & 0.4853 & \\
\hline d_Bit_1 & -0.849608 & 0.0639793 & -13.28 & $<0.0001$ & $* * *$ \\
\hline d_Bit_2 & -0.723278 & 0.0832664 & -8.686 & $<0.0001$ & $* * *$ \\
\hline d_Bit_3 & -0.547454 & 0.0922792 & -5.933 & $<0.0001$ & $* * *$ \\
\hline d_Bit_4 & -0.616260 & 0.0949611 & -6.490 & $<0.0001$ & $* * *$ \\
\hline d_Bit_5 & -0.444460 & 0.0956370 & -4.647 & $<0.0001$ & $* * *$ \\
\hline d_Bit_6 & -0.341730 & 0.0926324 & -3.689 & 0.0003 & $* * *$ \\
\hline d_Bit_7 & -0.176815 & 0.0825179 & -2.143 & 0.0332 & $* *$ \\
\hline d_Bit_8 & -0.155129 & 0.0634682 & -2.444 & 0.0152 & $* *$ \\
\hline R-squared & 0.475120 & & & & \\
\hline $\begin{array}{l}\text { All lags of gold } \\
\mathrm{F}(8,237)=\end{array}$ & 1.1144 & $(0.3541)$ & & & \\
\hline $\begin{array}{l}\text { All lags of } \\
\text { d_Bit } F(8, \\
23 \overline{3} 7)=\end{array}$ & 25.117 & $(0.0000)$ & & & \\
\hline $\begin{array}{l}\text { All vars, lag } 8 \\
\mathrm{~F}(2,237)=\end{array}$ & 3.2589 & $(0.0402)$ & & & \\
\hline Autocorr. & $F(4,468)$ & $(0.6992)$ & & & \\
\hline ARCH effect & $17.801(9)$ & $(0.0376)$ & & & \\
\hline
\end{tabular}

Source: (Author's)

The absence of autocorrelation indicates the consistency of the estimator since the data were independently distributed. The absence of an ARCH effect for a confidence level of $1 \%$ means that there is conditional homoskedasticity. The results of the causality test indicate that model 1 rejects the null hypothesis that a change in the value and price of Bitcoin is not causality in the Granger sense, or in the second model it accepts the null hypothesis that a change in the price of gold is not a causality in the change of the value and price of Bitcoin. In other words, these findings suggest that one cannot better predict the movement of the Bitcoin price by applying a series of data related to the movement 
of the gold price, in comparison to the case when using the historical data series of the value, that is, the price of Bitcoin. In simple terms, the movement of the price of gold cannot be used to predict future Bitcoin prices. On the other hand, the results show that the movement of the price of Bitcoin can be used to predict the price of gold in the world market.

\section{Conclusion}

This paper is devoted to investigating the existence of a cause and effect relationship in Grangers' sense between the movement of the Bitcoin price and the price of gold in the global market to answer the question whether it is possible to predict the movement of the value and price of Bitcoin based on data on the movement of the price of gold from the previous period, but also vice versa. The survey was conducted in the period from 1 January to 31 December 2019.

The research results show that historical data on the movement of gold prices in the world market cannot be used to predict the change in value and price movements of Bitcoin. On the other hand, the survey results indicate the possibility of a reliable application of the use of historical data on the movement of value and price of Bitcoin.

\section{References}

Balduzzi, P., Elton, E. and Green, T. (2001). Economic News and Bond Prices: Evidence from the U.S. Treasury Market. Journal of Financial and Quantitative Analysis, 36(4), 523-43.

Bradfield, J., (2007), Introduction to the Economics of Financial Markets, Oxford University Press, Oxford,

Chiarella, C., Kang, B., Nikitopoulos, C. S., and To, T-D. (2016). The return-volatility relation in commodity futures markets. Journal of Futures Markets, 36, 127-152.

Curcic, N., et al. (2020), Examining Causality Between Market Share and Profitability, Textile industry, (in printing).

Djordjevic, A., (2018), Primena naprednih tehnilogija u oblasti međunarodnih finansija, Ekonomika, Vol. 64, No. 1, str. 95-104.

Fama, E., (1970), "Efficient capital markets: A review of theory and empirical work", The Journal of Finance, No. 25, pp. 383-417.

Federal Register. (2011). Bank Secrecy Act Regulations; Definitions and Other Regulations Relating to Money Services.

Glaser F., Zimmermann K., Haferkorn M., Moritz C., Siering M. (2014). Bitcoin -asset or currency? Revealing users' hidden intentions, Twenty Second European

Conference on Information Systems, Tel Aviv.

Granger, C.W.J. (1969). Investigating causal relation by econometric and crosssectional method, Econometrica, 37, 424-438. 
Karpoff, J.M. (1987). The relation between price changes and trading volume: a survey. Journal of Financial and Quantitative Analysis, 22, 109-126

Kristoufek, L. (2014). What are the main drivers of the Bitcoin price? Evidence from wavelet coherence analysis. PLoS ONE 10(4): e0123923. doi:10.1371/journal. pone. 0123923

Kubát M. (2015), Virtual currency bitcoin in the scope of money definition and store of value, Procedia Economics and Finance, 30, 409 - 416.

Li, H., Zhong, W. and Park, S.Y. (2016). Generalized cross-spectral test for nonlinear Granger causality with applications to money-output and price-volume relations. Economic Modelling, 52, 661-671.

Mousavi, H. (2018). The U.S. financial crisis and its impact on the global oil market. International Review, (1-2), 119-130.

Peters, E., (1994), Fractal Marкet Analysis: Applying Chaos Theory to Investment Analyzing and Forecasting Futures Prices and Economics, John Wiley and Sons, Chichester.

Puri, T.N. and Philippatos, G.C. (2008). Asymmetric Volume-Return Relation and Concentrated Trading in LIFFE Futures. European Financial Management, 14, $528-563$.

Radivojevic, N., et al. (2019), „Econometric model of non-performing loans determinants", Physica A: Statistical Mechanics and its Applications, 520(April), 481-488.

Radivojevic, N., et al (2016), The new hybrid VaR approach based on EVT. Estudios de Economia, 43(1), 29-52.

Radivojevic, N., Sabot-Matic, Z., Mirjancic, B., (2017a): "New Historical bootstrap value at risk model", Journal of risk model validation, Vol. 11, No. 4, pp. 57-75.

Радивојевић, Н., (2014), Управљање тржишним ризицима на финансијским тржиштима у настајању применом модела вредности при ризику, Докторска дисертације, Економски факултет у Крагујевцу.

Radivojevic, N., Curcic, V., N., Vukajlovic, Dj. (2017b). Hull-White's VaR model: Case study of Baltic Equities market, Journal of Business economics and Management, 18(5), 1023-1041.

Smigić-Miladinović, J., (2018), Bitcoin - stanje i trendovi, Ekonomika, Vol. 64, No. 4, str. 109-120. 